\title{
Interaksi Wilayah di Kawasan Strategis Nasional (Perbatasan) dalam Kerangka Jaringan Perkotaan
}

\author{
Syaiful Muazir \\ Program Studi Arsitektur, Fakultas Teknik, Universitas Tanjungpura \\ Pontianak, Indonesia
}

Artikel Masuk : 14 Januari 2018

Artikel Diterima : 28 Februari 2019

Tersedia Online : 30 April 2019

\begin{abstract}
Abstrak: Dalam mendukung pembangunan di kawasan tertinggal (kawasan perbatasan), Pemerintah Indonesia telah mendorong kawasan-kawasan perkotaan di perbatasan untuk menjadi kawasan strategis yang mempunyai prioritas tertentu. Kawasan-kawasan tertentu menjadi pusat pertumbuhan untuk selanjutnya mentransfer hasil-hasil pembangunan terhadap kawasan lainnya. Salah satu kabupaten perbatasan yang ada di Provinsi Kalimantan Barat adalah Kabupaten Sambas. Terdapat dua kategori kawasan strategis di kabupaten ini yaitu Kecamatan Sambas (ibukota kabupaten) sebagai kawasan strategis pariwisata dan perbatasan (Temajuk dan Aruk) sebagai Pusat Kegiatan Strategis Nasional (PKSN). Dua kawasan strategis ini diharapkan dapat berinteraksi secara seimbang dan merata untuk pengembangan wilayah. Penelitian ini merupakan eksplorasi awal yang bertujuan untuk mengidentifikasi kecenderungan interaksi antarkawasan. Interaksi dianggap penting karena selama ini kawasan perbatasan merupakan kawasan tertinggal yang perlu didukung oleh kawasan lain dalam menyalurkan hasil-hasil pembangunan. Penelitian ini menggunakan pendekatan prinsip dari analisis jaringan yang menggunakan tipe-tipe jaringan di antaranya jaringan teknikal (infrastruktur), jaringan transaksional, dan jaringan sosial. Hasil dari studi ini menunjukkan bahwa interaksi antarkawasan maju dan tertinggal cenderung belum optimal. Kecamatan Sambas cenderung lebih berorientasi pada bagian selatan menuju arah ibukota provinsi, sedangkan kawasan perbatasan cenderung berorientasi ke negara tetangga serta kawasan-kawasan (internal) maju lainnya di sekitar area perbatasan.
\end{abstract}

Kata Kunci: interaksi; jaringan; kawasan; perbatasan; strategis

\begin{abstract}
To support the development of lagging areas (border areas), the Government of Indonesia has encouraged urban areas in the border to become strategic areas with certain development priorities. These specified areas could become a growth center for "transferring" the development outputs to the other areas. One of the border regency in West Kalimantan Province is Sambas Regency. There are two categories of "strategic areas" in this regency, that is Sambas District (the regency's capital city) as a tourism strategic area, and border area (Temajuk and Aruk) as the National Strategic Activities Center. Expectedly, these two strategic areas could interact more balanced and equally in regional development. This research deals with preliminary exploration which aims to identify the tendency of regional interaction in the strategic areas. Interaction is considerably important for the lagging areas in the border to distribute development outputs from other areas. This study applies the principle approach of network analysis by using different network types such as technical
\end{abstract}

\footnotetext{
${ }^{1}$ Korespondensi Penulis: Program Studi Arsitektur, Fakultas Teknik, Universitas Tanjungpura, Pontianak, Indonesia email: syaifulmuazir@teknik.untan.ac.id
} 


\section{Interaksi Wilayah di Kawasan Strategis Nasional (Perbatasan) dalam Kerangka Jaringan Perkotaan}

networks (infrastructure), transactional networks, and social networks. The results show that the interaction between developed and lagging areas has not been optimal yet. Sambas District is more attracted to the south closing to the provincial capital city while the border areas more attached to neighboring countries as well as other advanced (internal) areas next to the border.

Keywords: areas; border; interaction; network; strategic

\section{Pendahuluan}

Menanggapi masalah perkotaan yang semakin meningkat, Indonesia telah mengembangkan kerangka aturan tata ruang yang sesuai dengan karakteristik dan latar belakang nasional. Undang-Undang (UU) yang digunakan saat ini adalah UU Penataan Ruang Nomor 26 Tahun 2007. Berdasarkan UU tersebut, kegiatan perencanaan tata ruang akan menghasilkan dua rencana, yaitu rencana umum dan rencana detail. Selain itu, khususnya pada rencana detail, dikenal dengan kawasan strategis. Kawasan strategis merupakan daerah khusus yang mempunyai nilai penting dan prioritas nasional (strategis) dalam beberapa pertimbangan. Selain itu, dalam sistem hierarki perkotaan beberapa wilayah juga dipromosikan menjadi Pusat Kegiatan Strategis Nasional (PKSN) yang didefinisikan sebagai daerah perkotaan yang ditugaskan untuk mendorong pembangunan di sejumlah wilayah perbatasan nasional. Sejauh ini ada 26 PKSN yang tersebar di seluruh Indonesia. Pada tingkat provinsi jumlah wilayah strategis terbanyak terdapat di Kalimantan Barat (Kalbar) dengan lima wilayah perbatasan, diikuti Kalimantan Timur dan Maluku dengan empat wilayah perbatasan.

Salah satu kabupaten perbatasan di Provinsi Kalbar adalah Kabupaten Sambas yang terletak di bagian utara. Wilayah ini memiliki luas $6.395,70 \mathrm{~km}^{2}$ atau sekitar $4,36 \%$ dari luas wilayah provinsi $\left(146.807 \mathrm{~km}^{2}\right)$. Seperti yang tercatat dalam publikasi BPS Kabupaten Sambas (2017), Kabupaten Sambas terbagi menjadi 19 kecamatan dan 183 desa. Sebelumnya, daerah perbatasan atau daerah luar di Indonesia mempunyai keterbatasan dalam pembangunan daerah. Saat ini dengan semangat reformasi dan otonomi daerah, pemerintah pusat melalui undang-undang dan peraturan lainnya telah memberikan perhatian khusus kepada daerah perbatasan melalui pembentukan kawasan strategis, baik di sistem perkotaan (dalam struktur ruang) maupun kawasan strategis nasional (dalam pola spasial). Semua peraturan tersebut memberikan arahan kepada pemerintah daerah untuk memberikan perhatian khusus dan mendorong percepatan pembangunan di daerah perbatasan. Dalam mendorong Kabupaten Sambas sebagai kabupaten perbatasan, pemerintah telah menetapkan beberapa kawasan strategis (PKSN) tepatnya di area-area perbatasan (Paloh dan Aruk). Selain itu, dalam perspektif pembangunan lainnya (pariwisata), Sambas dan sekitarnya juga telah ditetapkan menjadi kawasan strategis pariwisata nasional.

Kawasan perbatasan adalah lokasi fisik atau ruang diskursif di sepanjang perbatasan politik dan fisik yang dikembangkan secara historis, yang perbedaannya dibangun terutama antara negara-bangsa, dunia pertama dan ketiga, serta penjajah dan terjajah (Wasti-Walter, 2009). Wasti-Walter (2009) juga mengatakan bahwa perbatasan adalah ruang yang di dalamnya terdapat sistem normatif yang saling bertemu (penghalang, mengendalikan), berfungsi sebagai jembatan (manfaat dalam sosial, budaya, ekonomi), sebagai ruang fungsional (manfaat dari area), berfungsi sebagai penghalang atau penghambat, dan dapat terus berubah fungsi. Curt Muller-Lobau (dalam Murdock, 2010) menyebutkan bahwa perbatasan menciptakan pengaruh dua negara dan budaya yang saling berhadapan satu sama lain. 


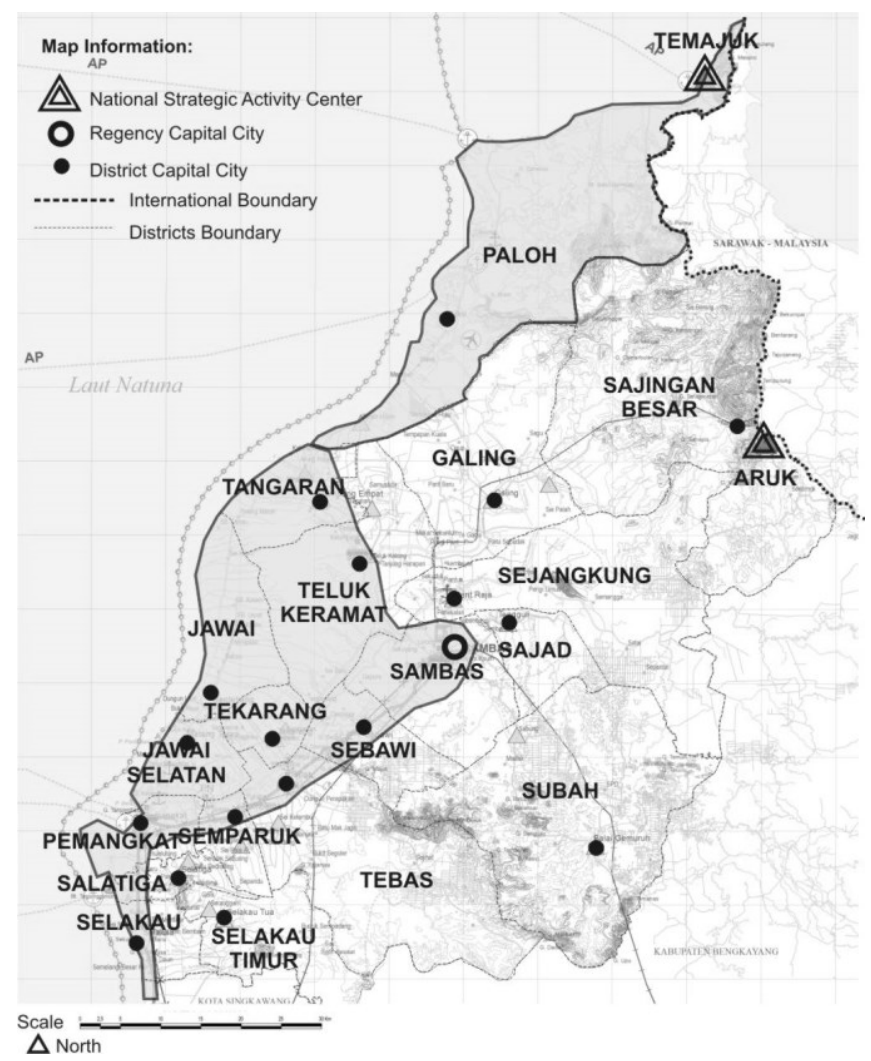

Sumber: Pemerintah Kabupaten Sambas, 2012

\section{Gambar 1. Kabupaten Sambas dan Kawasan Strategis}

Terkait dengan kawasan perbatasan di Kalimantan Barat, menurut Muazir \& Hsieh (2013), masalah umum kawasan perbatasan adalah aksesibilitas (isolasi), fasilitas, infrastruktur, transportasi, dan telekomunikasi. Selain itu, dibandingkan dengan bagian Sarawak, Malaysia, kawasan perbatasan sebagian besar telah dilengkapi dengan jalan (transportasi dan akses yang baik), listrik, telepon, dan akses perawatan kesehatan. Selain itu, pusat-pusat komersial dan tempat-tempat wisata dirancang dengan baik dan menarik. Oleh karena itu, banyak orang Indonesia yang tinggal di daerah perbatasan lebih suka berkunjung ke Malaysia. Sebagai upaya untuk menyelesaikan masalah tersebut, Pemerintah Indonesia melalui kebijakan spasial dan kebijakan menteri lainnya telah menyetujui beberapa rencana untuk mempromosikan pembangunan di kawasan perbatasan. Salah satunya adalah Peraturan Pemerintah (PP) tentang Rencana Tata Ruang Wilayah Nasional (RTRWN) tahun 2008 yang saat ini telah diperbarui menjadi PP Nomor 13 Tahun 2017 tentang Perubahan Atas Peraturan Pemerintah Nomor 26 Tahun 2008 tentang RTRWN. Peraturan ini telah menunjukkan beberapa upaya untuk meningkatkan pembangunan daerah perbatasan dengan mempromosikan kawasan perbatasan untuk menjadi daerah strategis dan pusat pembangunan perkotaan yang tentunya akan memberikan interaksi dan konektivitas yang baik dengan wilayah maju lainnya.

Tujuan utama dari kegiatan perencanaan adalah menentukan daerah-daerah distribusi terhadap kegiatan dan pembangunan (Glasson \& Marshall, 2007). Ditinjau dari pendekatan teori pertumbuhan ekonomi, penyebab dan konsekuensi dari disparitas atau ketidakseimbangan antardaerah dapat dikaji melalui perspektif interaksi antardaerah. Secara sederhana, interaksi daerah dapat dipahami sebagai pergerakan antardaerah dalam tingkat hierarki yang sama, baik horizontal maupun vertikal (Nazara, Hewings, \& Sonis, 2006). Dalam pengertian umum, interaksi dapat diartikan sebagai pertukaran, tetapi bisa 


\section{Interaksi Wilayah di Kawasan Strategis Nasional (Perbatasan) dalam Kerangka Jaringan Perkotaan}

saja terjadi tanpa mengubah satu dengan yang lainnya (Edmonds, 2007). Sebuah daerah hendaknya berhubungan antara satu dan yang lainnya, untuk berinteraksi serta berbagi aliran barang dan jasa. Konektivitas dapat diartikan sebagai kemudahan perpindahan dari satu lokasi ke lokasi lainnya dari manusia, material, atau informasi (Sokol, 2009). Dilanjutkan oleh Glasson \& Marshall (2007), konektivitas dapat diwujudkan sebagai infrastruktur transportasi, telekomunikasi, dan jaringan usaha atau bisnis. Melalui konektivitas, suatu daerah dapat mendorong dan meningkatkan koneksi antarmanusia, barang, dan daerah (Staeheli, 2012), sebagaimana juga akan berdampak secara langsung pada sektor ekonomi dan aliran usaha-usaha antardaerah (Lobo-Guerrero, 2012). Konektivitas dan akses yang baik dapat mendorong hubungan antardaerah yang dapat menghubungkan lebih baik antara produsen dan konsumen yang pada akhirnya dapat meningkatkan pertumbuhan ekonomi (Vega, 2012), dan tentunya berdampak pada pembangunan sebuah daerah, khususnya daerah tertinggal atau perbatasan.

Konektivitas mempunyai hubungan yang erat dengan konsep analisis jaringan. Hadas (2013) menyebutkan bahwa banyak perhitungan konektivitas dalam sebuah jaringan dihitung dengan menggunakan pendekatan grafik. Konektivitas dalam grafik diidentifikasi dan dianalisis melalui ilustrasi jalur, titik, dan garis. Di dalam kajian geografi, Downs \& Horner (2012) mengatakan bahwa para ahli geografi menggunakan ilustrasi grafik dan pendekatan analisis jaringan (network analysis) untuk menganalisis hubungan antarlokasi dalam bentuk titik (node/vertices) dan penghubungnya (link/edge). Berkaitan dengan perencanaan perkotaan, Beauregard (dalam Albrechts \& Seymour, 2005) mengatakan sebuah kota atau kawasan regional dapat berisi atau terdiri dari beberapa seri sistem jaringan, seperti jaringan air, drainase, perumahan, transportasi, dan telekomunikasi. Dilanjutkan oleh Clarke (2009), pada awal abad ke-20, istilah jaringan perkotaan (urban network) telah digunakan dan difungsikan dalam ekonomi global dan infrastruktur.

Merespon berkembangnya analisis jaringan serta hubungannya dengan perkotaan, Heydebrand (1999) mengatakan bahwa terdapat tiga tipe berbeda untuk memahami lebih lanjut jaringan sebagai metafora, yaitu jaringan teknikal, jaringan transaksional, dan jaringan sosial. Jaringan teknikal berupa telepon, internet, dan infrastruktur lainnya. Neuman (2006) menyebutkan bahwa jenis infrastruktur terbagi ke dalam beberapa jenis, yaitu utilitas seperti gas dan listrik, pekerjaan umum seperti jalan raya dan jembatan, fasilitas sosial/komunitas seperti sekolah dan taman, telekomunikasi seperti telepon dan internet, transportasi, ilmu pengetahuan seperti universitas dan pusat studi. Jaringan transaksional dapat berwujud seperti transportasi dan perdagangan. Selain itu, pendekatan analisis jaringan sering digunakan untuk mengkaji keilmuan di bidang usaha, seperti untuk mengeskplorasi hubungan pada pemasaran, subkontraktor, penyedia, perserikatan, perdagangan, produksi bersama, dan investasi (Bassi, Zaccarin, \& De Stefano, 2014; Dale, 2003; Hedaa \& Törnroos, 2008; Miller, Besser, \& Malshe, 2007; Pache, 1990; Tinsley \& Lynch, 2001; Todeva, 2006). Menurut Oliveira \& Gama (2012), jaringan sosial disusun berdasarkan data hubungan atau relasi. Takahashi \& Sakamoto (2000) menyatakan bahwa kajian "tradisional" yang sering dikaji melalui jaringan sosial adalah hubungan seseorang terhadap lainnya, misalnya terhadap keluarganya ataupun perilaku sosial individu di lingkungan sosialnya. Hubungan sosial dapat terjadi antarindividu, antarkelompok, dan antarindividu dengan kelompok.

Dalam pendekatan analisis jaringan, Borgatti, Everett, \& Johnson (2013) mengatakan setidaknya terdapat tiga pendekatan dasar dalam analisis jaringan yang dapat digunakan untuk melakukan perhitungan dan melihat kecenderungan, yaitu (1) keterpusatan atau sentralitas (centrality), (2) subgrafik atau kelompok (subgraph), dan (3) persamaan derajat (equivalence). Selain itu, masing-masing pendekatan juga mempunyai detail perhitungan seperti degree (derajat), closeness (kedekatan), betweenness (antara), eigenvector (vector Eigen), dan lain-lain. 
Secara umum, sebagai kawasan strategis, kondisi infrastruktur dan aksesibilitas di Kabupaten Sambas masih berorientasi ke kawasan sepanjang koridor utama yang menghubungkan daya tarik ekonomi utama yaitu ibukota provinsi (Kota Pontianak). Daerah-daerah yang mengarah ke Pontianak menjadi daerah dengan konektivitas tinggi dan lebih maju dibandingkan dengan kawasan perbatasan (Muazir \& Hsieh, 2016; Muazir, Hsieh, \& Lestari, 2014). Melihat kondisi tersebut, kawasan atau area maju (seperti Kecamatan Sambas dan sekitarnya) tampak belum berhasil "mentransfer" hasil-hasil pembangunan yang telah dilakukan apabila dilihat dari kesenjangan yang ada, seperti populasi, fasilitas, dan infrastruktur. Oleh karena itu, perlu adanya interaksi antara kawasan strategis secara seimbang yang memiliki distribusi yang sama sesuai dan karakteristik/spesifikasi kawasan masing-masing.

Berdasarkan permasalahan tersebut, penelitian ini merupakan tahap awal yang bertujuan mengidentifikasi detail karakter interaksi antarkawasan di kawasan perbatasan. Hasil penelitian sebelumnnya memperlihatkan bahwa arah interaksi cenderung belum maksimal di antara pusat kota dengan area perbatasan yang salah satunya dikarenakan oleh keterbatasan jarak dan infrastruktur. Kajian ini akan melihat dari beberapa faktor serta entitas dalam kajian analisis jaringan. Interaksi yang dieksplorasi pada tahap ini adalah interaksi dari kawasan strategi pariwisata atau ibukota Kabupaten Sambas yaitu Kecamatan Sambas terhadap kawasan perbatasan (PKSN) yaitu di Kecamatan Paloh, tepatnya di Temajuk. Dalam mengeksplorasi interaksi antardaerah, pendekatan yang digunakan adalah prinsip analisis jaringan yang mencoba untuk mencari hubungan antarentitas (Scott, Baggio, \& Cooper, 2008). Dalam menentukan unsur kajian, khususnya kajian kewilayahan, digunakan tipe-tipe jaringan yang dikembangkan dalam kerangka pengembangan keilmuan, yaitu analisis jaringan yang terbagi atas jaringan teknikal (infrastruktur), jaringan transaksional, dan jaringan sosial.

\section{Metode Penelitian}

Seperti dirangkum oleh Heydebrand (1999) sebelumnya, setidaknya terdapat tiga jaringan sebagai bentuk metafora dan pengembangan keilmuan analisis jaringan, termasuk di dalamnya keilmuan perencanaan kota atau wilayah. Adapun tiga unsur jaringan tersebut dapat berupa: (1) jaringan teknikal, seperti telepon, internet, dan infrastruktur lainnya; (2) jaringan transaksional, seperti transportasi, perdagangan; dan (3) jaringan sosial. Penelitian ini merupakan studi pendahuluan dalam penelitian jaringan perkotaan. Penelitian ini menekankan dua unsur jaringan perkotaan, khususnya transaksional (usaha) dan sosial untuk melihat kecenderungan interaksi (arah dan orientasi) antardaerah yang ada di kawasan perbatasan, khususnya Sambas, Temajuk, dan Paloh. Adapun jaringan teknikal (infrastruktur) lebih menekankan dukungan bagi kedua jaringan sebelumnya. Hal ini dilakukan karena luasnya substansi kajian dari jaringan teknikal tersebut apabila digabungkan dengan dua jaringan lainnya.

Penentuan faktor (variabel) penelitian merujuk pada konstruksi tinjauan teori yang memberikan arahan definisi masing-masing, khususnya pada jaringan sosial dan transaksional. Jaringan sosial memuat hubungan antarorang atau kelompok, sedangkan jaringan transaksional memuat hubungan usaha yang dimiliki. Terkait dengan kebutuhan data jaringan yang diperlukan, setidaknya terdapat tiga bentuk jaringan yang dapat dikembangkan untuk masing-masing jaringan seperti: (1) hubungan atau konektivitas, (2) relasi atau pertalian, dan (3) aliran atau arah (Borgatti et al., 2013; Knoke \& Yang, 2008; Scott et al., 2008). Dari rumusan tersebut, kebutuhan data jaringan setidaknya memuat unsur-unsur titik awal dan titik akhir (arah) maupun lokasi dan distribusi dari masingmasing jaringan. Merujuk pada masing-masing unsur jaringan serta definisi mengenai elemen/komponen di dalamnya, maka kebutuhan data diuraikan pada Tabel 1. 
Tabel 1. Kebutuhan Data

\begin{tabular}{|c|c|c|c|}
\hline No & Faktor (Variabel) & Level & (Kebutuhan) Data Jaringan \\
\hline \multirow{3}{*}{1} & \multirow{3}{*}{ Jaringan sosial } & \multirow{3}{*}{$\begin{array}{l}\text { Hubungan personal dan } \\
\text { keluarga }\end{array}$} & 1. Distribusi keluarga dan teman \\
\hline & & & 2. Kegiatan sosial (pergerakan) \\
\hline & & & 3. Kontak sosial (dengan media tertentu) \\
\hline \multirow{7}{*}{2} & \multirow{7}{*}{$\begin{array}{l}\text { Jaringan transaksional: } \\
\text { kegiatan usaha atau } \\
\text { bisnis }\end{array}$} & \multirow{7}{*}{ Tipe dan level usaha } & 1. Arah transaksi utama \\
\hline & & & 2. Lokasi supplier \\
\hline & & & 3. Bentuk kerja sama \\
\hline & & & 4. Cabang usaha \\
\hline & & & 5. Distribusi pegawai \\
\hline & & & 6. Asal konsumen \\
\hline & & & 7. Area penjualan \\
\hline
\end{tabular}

Sumber: Analisis Penulis, 2017

Secara umum, pengumpulan data menggunakan beberapa teknik, seperti observasi, kuesioner, serta wawancara dengan setiap data akan mendukung satu sama lain. Sampel (khususnya kuesioner) disesuaikan dengan kebutuhan serta menggunakan pendekatan jumlah sampel yang dikembangkan oleh Krejcie \& Morgan (1970). Analisis menggunakan salah satu pendekatan dari analisis jaringan, yaitu derajat (degree). Derajat adalah jumlah garis (tautan) yang berhubungan dengan satu titik dan jumlah tautan (garis) yang dimiliki oleh satu titik (Borgatti et al., 2013; Scott et al., 2008). Tujuan dari analisis derajat adalah mengukur frekuensi sebuah titik (wilayah) dalam berhubungan/berinteraksi keluar/ke dalam dengan wilayah lain. Dari data yang dikumpulkan, analisis juga dibantu dengan perangkat lunak UCINET (Borgatti, Everett, \& Freeman, 2002) dengan memperhitungkan banyaknya arah masuk (indegree) dan arah keluar (outdegree).

$$
k_{i}^{\text {in }}=\sum_{j} a_{j i} k_{i}^{\text {out }}=\sum_{j} a_{i j}
$$

Sumber: Scott et al, 2008

\section{Gambar 2. Algoritma Pengukuran Derajat}

\section{Hasil dan Pembahasan}

\section{Interaksi Sosial}

Pada bagian ini, eksplorasi dari jaringan sosial dilakukan melalui beberapa penelusuran informasi, di antaranya: (1) distribusi keluarga, (2) kunjungan keluarga, (3) distribusi teman, (4) distribusi tempat kerja, (5) tujuan ke kota utama, (6) tujuan ke negara tetangga, (7) lokasi kontak melalui media (telepon), dan (8) rute pergerakan harian. Dari kedelapan unsur pertanyaan tersebut, masing-masing dikelompokkan sesuai dengan kedekatan data menjadi hanya tiga unsur informasi, yaitu (1) distribusi sosial (keluarga dan teman), (2) pergerakan sosial (bekerja, ke kota, dan sebagainya), dan (3) kontak sosial melalui media (telepon). Adapun hasil pengukuran derajat interaksi sosial dapat dilihat pada Tabel 2, Tabel 3, dan Tabel 4. 
Tabel 2. Interaksi (Jaringan) Sosial

\begin{tabular}{|c|c|c|c|c|c|c|c|c|c|}
\hline \multirow{2}{*}{ No } & \multirow{2}{*}{ Jaringan } & \multicolumn{4}{|c|}{ Sambas } & \multicolumn{4}{|c|}{ Temajuk, Paloh } \\
\hline & & Kode & Area & OutDegree & InDegree & Kode & Area & OutDegree & InDegree \\
\hline \multirow{25}{*}{1} & \multirow{25}{*}{$\begin{array}{l}\text { Distribusi } \\
\text { Sosial }\end{array}$} & 12 & Sambas & 395.000 & 2.000 & 8 & Paloh & 397.000 & 0.000 \\
\hline & & 9 & Sajad & 1.000 & 3.000 & 1 & Bali & 0.000 & 1.000 \\
\hline & & 6 & Paloh & 1.000 & 22.000 & 3 & Galing & 0.000 & 6.000 \\
\hline & & 1 & $\begin{array}{l}\text { Timur } \\
\text { Kalbar } \\
\end{array}$ & 0.000 & 20.000 & 4 & Jawa & 0.000 & 21.000 \\
\hline & & 2 & Galing & 0.000 & 14.000 & 5 & Jawai & 0.000 & 85.000 \\
\hline & & 4 & Jawai & 0.000 & 20.000 & 6 & $\begin{array}{l}\text { Jawai } \\
\text { Selatan } \\
\end{array}$ & 0.000 & 3.000 \\
\hline & & 5 & Malaysia & 0.000 & 5.000 & 7 & $\begin{array}{l}\text { Pulau } \\
\text { Kalimantan } \\
\end{array}$ & 0.000 & 3.000 \\
\hline & & 7 & Papua & 0.000 & 1.000 & 2 & $\begin{array}{l}\text { Timur } \\
\text { Kalbar } \\
\end{array}$ & 0.000 & 13.000 \\
\hline & & 8 & Pemangkat & 0.000 & 24.000 & 9 & Pemangkat & 0.000 & 11.000 \\
\hline & & 10 & $\begin{array}{l}\text { Sajingan } \\
\text { Besar } \\
\end{array}$ & 0.000 & 2.000 & 10 & Philippines & 0.000 & 1.000 \\
\hline & & 11 & Salatiga & 0.000 & 1.000 & 11 & $\begin{array}{l}\text { Sajingan } \\
\text { Besar } \\
\end{array}$ & 0.000 & 2.000 \\
\hline & & 3 & Jawa & 0.000 & 10.000 & 12 & Salatiga & 0.000 & 1.000 \\
\hline & & 13 & Sarawak & 0.000 & 3.000 & 13 & Sambas & 0.000 & 32.000 \\
\hline & & 14 & Sebawi & 0.000 & 16.000 & 14 & Sarawak & 0.000 & 30.000 \\
\hline & & 15 & Sejangkung & 0.000 & 25.000 & 15 & Sebawi & 0.000 & 2.000 \\
\hline & & 16 & Selakau & 0.000 & 5.000 & 16 & Selakau & 0.000 & 9.000 \\
\hline & & 17 & $\begin{array}{l}\text { Selakau } \\
\text { Timur } \\
\end{array}$ & 0.000 & 1.000 & 17 & $\begin{array}{l}\text { Selakau } \\
\text { Timur } \\
\end{array}$ & 0.000 & 2.000 \\
\hline & & 18 & Semparuk & 0.000 & 3.000 & 18 & Semparuk & 0.000 & 3.000 \\
\hline & & 19 & $\begin{array}{l}\text { Selatan } \\
\text { Kalbar } \\
\end{array}$ & 0.000 & 102.000 & 19 & $\begin{array}{l}\text { Selatan } \\
\text { Kalbar } \\
\end{array}$ & 0.000 & 71.000 \\
\hline & & 20 & Subah & 0.000 & 3.000 & 20 & Subah & 0.000 & 2.000 \\
\hline & & 21 & Sumatera & 0.000 & 3.000 & 21 & Sumatra & 0.000 & 14.000 \\
\hline & & 22 & Tangaran & 0.000 & 5.000 & 22 & Tangaran & 0.000 & 22.000 \\
\hline & & 23 & Tebas & 0.000 & 59.000 & 23 & Tebas & 0.000 & 14.000 \\
\hline & & 24 & Tekarang & 0.000 & 4.000 & 24 & Tekarang & 0.000 & 4.000 \\
\hline & & 25 & $\begin{array}{l}\text { Teluk } \\
\text { Keramat }\end{array}$ & 0.000 & 44.000 & 25 & $\begin{array}{l}\text { Teluk } \\
\text { Keramat }\end{array}$ & 0.000 & 45.000 \\
\hline \multirow{24}{*}{2} & \multirow{24}{*}{$\begin{array}{l}\text { Pergerakan } \\
\text { Sosial }\end{array}$} & 12 & Sambas & 961.000 & 0.000 & 8 & Paloh & 993.000 & 0.000 \\
\hline & & 1 & $\begin{array}{l}\text { Timur } \\
\text { Kalbar }\end{array}$ & 0.000 & 25.000 & 2 & $\begin{array}{l}\text { Timur } \\
\text { Kalbar }\end{array}$ & 0.000 & 8.000 \\
\hline & & 2 & Galing & 0.000 & 15.000 & 1 & Bali & 0.000 & 1.000 \\
\hline & & 4 & Jawai & 0.000 & 21.000 & 4 & Jawa & 0.000 & 4.000 \\
\hline & & 5 & $\begin{array}{l}\text { Jawai } \\
\text { Selatan } \\
\end{array}$ & 0.000 & 1.000 & 5 & Jawai & 0.000 & 117.000 \\
\hline & & 3 & Jawa & 0.000 & 3.000 & 6 & $\begin{array}{l}\text { Jawai } \\
\text { Selatan } \\
\end{array}$ & 0.000 & 1.000 \\
\hline & & 7 & Paloh & 0.000 & 31.000 & 7 & Malaysia & 0.000 & 4.000 \\
\hline & & 8 & Pemangkat & 0.000 & 97.000 & 3 & Galing & 0.000 & 3.000 \\
\hline & & 9 & Sajad & 0.000 & 8.000 & 9 & Pemangkat & 0.000 & 11.000 \\
\hline & & 10 & $\begin{array}{l}\text { Sajingan } \\
\text { Besar }\end{array}$ & 0.000 & 8.000 & 10 & $\begin{array}{l}\text { Sajingan } \\
\text { Besar } \\
\end{array}$ & 0.000 & 1.000 \\
\hline & & 11 & Salatiga & 0.000 & 1.000 & 11 & Sambas & 0.000 & 81.000 \\
\hline & & 6 & Malaysia & 0.000 & 6.000 & 12 & Sarawak & 0.000 & 584.000 \\
\hline & & 13 & Sarawak & 0.000 & 47.000 & 13 & Selakau & 0.000 & 3.000 \\
\hline & & 14 & Sebawi & 0.000 & 18.000 & 14 & $\begin{array}{l}\text { Selakau } \\
\text { Timur }\end{array}$ & 0.000 & 5.000 \\
\hline & & 15 & Sejangkung & 0.000 & 31.000 & 15 & Semparuk & 0.000 & 2.000 \\
\hline & & 16 & Selakau & 0.000 & 8.000 & 16 & $\begin{array}{l}\text { Selatan } \\
\text { Kalbar }\end{array}$ & 0.000 & 36.000 \\
\hline & & 17 & Semparuk & 0.000 & 5.000 & 17 & Subah & 0.000 & 4.000 \\
\hline & & 18 & $\begin{array}{l}\text { Selatan } \\
\text { Kalbar } \\
\end{array}$ & 0.000 & 465.000 & 18 & Sumatra & 0.000 & 22.000 \\
\hline & & 19 & Subah & 0.000 & 23.000 & 19 & Tangaran & 0.000 & 8.000 \\
\hline & & 20 & $\begin{array}{l}\text { Sumatra } \\
\end{array}$ & 0.000 & 1.000 & 20 & $\begin{array}{l}\text { Tebas } \\
\end{array}$ & 0.000 & 12.000 \\
\hline & & 21 & Tangaran & 0.000 & 10.000 & 21 & Tekarang & 0.000 & 4.000 \\
\hline & & 22 & Tebas & 0.000 & 98.000 & 22 & $\begin{array}{l}\text { Teluk } \\
\text { Keramat }\end{array}$ & 0.000 & 82.000 \\
\hline & & 23 & Tekarang & 0.000 & 4.000 & & & & \\
\hline & & 24 & $\begin{array}{l}\text { Teluk } \\
\text { Keramat }\end{array}$ & 0.000 & 35.000 & & & & \\
\hline \multirow{14}{*}{3} & \multirow{14}{*}{$\begin{array}{l}\text { Kontak } \\
\text { Sosial } \\
\text { (dengan } \\
\text { media) }\end{array}$} & 10 & Sambas & 137.000 & 0.000 & 9 & Paloh & 196.000 & 0.000 \\
\hline & & 2 & Galing & 0.000 & 3.000 & 1 & Bali & 0.000 & 1.000 \\
\hline & & 3 & Jawa & 0.000 & 5.000 & 3 & Galing & 0.000 & 5.000 \\
\hline & & 4 & Jawai & 0.000 & 6.000 & 2 & $\begin{array}{l}\text { Timur } \\
\text { Kalbar } \\
\end{array}$ & 0.000 & 7.000 \\
\hline & & 5 & Malaysia & 0.000 & 3.000 & 5 & Jawai & 0.000 & 39.000 \\
\hline & & 6 & Paloh & 0.000 & 6.000 & 6 & $\begin{array}{l}\text { Jawai } \\
\text { Selatan } \\
\end{array}$ & 0.000 & 1.000 \\
\hline & & 7 & Pemangkat & 0.000 & 9.000 & 7 & Kalimantan & 0.000 & 1.000 \\
\hline & & 8 & $\begin{array}{l}\text { Sajingan } \\
\text { Besar }\end{array}$ & 0.000 & 1.000 & 8 & Malaysia & 0.000 & 6.000 \\
\hline & & 9 & Salatiga & 0.000 & 1.000 & 4 & Jawa & 0.000 & 16.000 \\
\hline & & 1 & $\begin{array}{l}\text { Timur } \\
\text { Kalbar }\end{array}$ & 0.000 & 4.000 & 10 & Pemangkat & 0.000 & 7.000 \\
\hline & & 11 & Sebawi & 0.000 & 6.000 & 11 & $\begin{array}{l}\text { Sajingan } \\
\text { Besar }\end{array}$ & 0.000 & 1.000 \\
\hline & & 12 & Sejangkung & 0.000 & 9.000 & 12 & Ssmbas & 0.000 & 15.000 \\
\hline & & 13 & Selakau & 0.000 & 1.000 & 13 & Sarawak & 0.000 & 7.000 \\
\hline & & 14 & $\begin{array}{l}\text { Selatan } \\
\text { Kalbar } \\
\end{array}$ & 0.000 & 44.000 & 14 & Selakau & 0.000 & 1.000 \\
\hline
\end{tabular}




\section{Interaksi Wilayah di Kawasan Strategis Nasional (Perbatasan) dalam Kerangka Jaringan Perkotaan}

\section{Lanjutan Tabel 2}

\begin{tabular}{|c|c|c|c|c|c|c|c|c|c|}
\hline \multirow{9}{*}{ No } & \multirow{9}{*}{ Jaringan } & \multicolumn{4}{|c|}{ Sambas } & \multicolumn{4}{|c|}{ Temajuk, Paloh } \\
\hline & & Kode & Area & OutDegree & InDegree & Kode & Area & OutDegree & InDegree \\
\hline & & 15 & Subah & 0.000 & 2.000 & 15 & $\begin{array}{l}\text { Selakau } \\
\text { Timur }\end{array}$ & 0.000 & 2.000 \\
\hline & & 17 & Tangaran & 0.000 & 2.000 & 17 & $\begin{array}{l}\text { Selatan } \\
\text { Kalbar }\end{array}$ & 0.000 & 45.000 \\
\hline & & 18 & Tebas & 0.000 & 23.000 & 18 & Subah & 0.000 & 2.000 \\
\hline & & 19 & $\begin{array}{l}\text { Teluk } \\
\text { Keramat }\end{array}$ & 0.000 & 8.000 & 19 & Sumatra & 0.000 & 7.000 \\
\hline & & & & & & 21 & Tebas & 0.000 & 4.000 \\
\hline & & & & & & 22 & Tekarang & 0.000 & 1.000 \\
\hline & & & & & & 23 & $\begin{array}{l}\text { Teluk } \\
\text { Keramat }\end{array}$ & 0.000 & 20.000 \\
\hline
\end{tabular}

Sumber: Analisis Penulis, 2016

Tabel 3. Dukungan Infrastruktur dalam Jaringan Sosial di Sambas

\begin{tabular}{|c|c|c|c|c|c|}
\hline Variabel & Kategori & $\%$ & Variabel & Kategori & $\%$ \\
\hline \multirow{2}{*}{ Jalan } & Mendukung & 78.5 & \multirow{2}{*}{ Persampahan } & Mendukung & 79.8 \\
\hline & TidakMendukung & 21 & & TidakMendukung & 19.7 \\
\hline \multirow{2}{*}{ Listrik } & Mendukung & 79 & \multirow{2}{*}{ Telekomunikasi } & Mendukung & 86.9 \\
\hline & TidakMendukung & 20.5 & & TidakMendukung & 12.3 \\
\hline \multirow[b]{2}{*}{ Air Bersih } & Mendukung & 75.3 & \multirow[b]{2}{*}{ Koneksi Internet } & Mendukung & 87.9 \\
\hline & $\begin{array}{l}\text { Tidak } \\
\text { Mendukung }\end{array}$ & 23.4 & & TidakMendukung & 11.3 \\
\hline \multirow{4}{*}{$\begin{array}{l}\text { Fasilitas } \\
\text { Paling Buruk }\end{array}$} & Listrik & 22.6 & \multirow{4}{*}{$\begin{array}{l}\text { Fasilitas Paling } \\
\text { Baik }\end{array}$} & Jalan & 25.5 \\
\hline & Jalan & 14.2 & & Pendidikan & 17.6 \\
\hline & Air Bersih & 12.3 & & Telekomunikasi & 13.6 \\
\hline & Lainnya & - & & Lainnya & - \\
\hline \multirow{4}{*}{$\begin{array}{l}\text { Durasi ke } \\
\text { Perbatasan }\end{array}$} & $\begin{array}{l}\text { Satu Kali } \\
\text { Setahun }\end{array}$ & 22 & \multirow{4}{*}{$\begin{array}{l}\text { Durasi ke Arah } \\
\text { Kota Utama }\end{array}$} & Satu Kali Sebulan & 16.8 \\
\hline & $\begin{array}{l}\text { Satu Kali } \\
\text { Sebulan }\end{array}$ & 5 & & Satu Kali Setahun & 8.7 \\
\hline & Dua Kali Setahun & 5 & & $\begin{array}{l}\text { Satu Kali } \\
\text { Seminggu }\end{array}$ & 4.5 \\
\hline & Lainnya & - & & Lainnya & - \\
\hline \multirow{4}{*}{$\begin{array}{l}\text { Alasan ke } \\
\text { Perbatasan }\end{array}$} & Rekreasi & 13.1 & \multirow{4}{*}{ Alasan ke Kota } & $\begin{array}{l}\text { Kunjungan } \\
\text { Keluarga }\end{array}$ & 17.1 \\
\hline & Tujuan Keluarga & 6.6 & & Rekreasi & 8.7 \\
\hline & Bekerja & 5.2 & & Belanja & 5.2 \\
\hline & Lainnya & - & & Bekerja & 4.5 \\
\hline
\end{tabular}

Sumber: Hasil Survei, 2016

Tabel 4. Dukungan Infrastruktur dalam Jaringan Sosial di Temajuk, Paloh

\begin{tabular}{|c|c|c|c|c|c|}
\hline Variabel & Kategori & $\%$ & Variabel & Kategori & $\%$ \\
\hline \multirow{2}{*}{ Jalan } & Mendukung & 91.1 & \multirow{2}{*}{ Persampahan } & Mendukung & 42.7 \\
\hline & TidakMendukung & 8.9 & & TidakMendukung & 57.3 \\
\hline \multirow{2}{*}{ Listrik } & Mendukung & 8.5 & \multirow{2}{*}{ Telekomunikasi } & Mendukung & 0.3 \\
\hline & TidakMendukung & 91.5 & & TidakMendukung & 99.7 \\
\hline \multirow{2}{*}{ Air Bersih } & Mendukung & 67.4 & \multirow{2}{*}{ Koneksi Internet } & Mendukung & 1.9 \\
\hline & TidakMendukung & 32.6 & & TidakMendukung & 98.1 \\
\hline \multirow{4}{*}{$\begin{array}{l}\text { Fasilitas } \\
\text { Paling Buruk }\end{array}$} & Listrik & 45.3 & \multirow{4}{*}{$\begin{array}{l}\text { Fasilitas Paling } \\
\text { Baik }\end{array}$} & Jalan & 63.3 \\
\hline & Telekomunikasi & 15.2 & & Pendidikan & 20.3 \\
\hline & $\begin{array}{l}\text { Listrik, } \\
\text { Telekomunikasi }\end{array}$ & 13 & & Jalan, Pendidikan & 10.8 \\
\hline & Lainnya & - & & Lainnya & \\
\hline Durasi ke & Satu Kali Sebulan & 29.1 & Durasi ke Arah & Satu Kali Sebulan & 25 \\
\hline
\end{tabular}


Lanjutan Tabel 4

\begin{tabular}{|c|c|c|c|c|c|}
\hline Variabel & Kategori & $\%$ & Variabel & Kategori & $\%$ \\
\hline \multirow[t]{3}{*}{ Perbatasan } & Satu Kali Setahun & 18.4 & \multirow[t]{3}{*}{ Kota Utama } & Satu Kali Setahun & 24.4 \\
\hline & $\begin{array}{l}\text { Satu Kali } \\
\text { Seminggu }\end{array}$ & 14.9 & & Dua Kali Setahun & 10.1 \\
\hline & Lainnya & - & & Lainnya & - \\
\hline \multirow{4}{*}{$\begin{array}{l}\text { Alasan ke } \\
\text { Perbatasan }\end{array}$} & Rekreasi & 27.5 & \multirow{4}{*}{ Alasan ke Kota } & $\begin{array}{l}\text { Kunjungan } \\
\text { Keluarga }\end{array}$ & 42.7 \\
\hline & Belanja & 28.2 & & Belanja & 17.1 \\
\hline & Perayaan Hari Raya & 13.6 & & Bekerja & 5.7 \\
\hline & Lainnya & - & & Lainnya & - \\
\hline
\end{tabular}

Sumber: Hasil Survei, 2016

Di Sambas, distribusi sosial lebih berorientasi ke bagian selatan Kalimantan Barat/Sambas (menuju arah Kota Pontianak) dan daerah terdekat lainnya seperti Tebas, Teluk Keramat, dan lain-lain. Pergerakan aktivitas sosial juga berorientasi ke bagian selatan Sambas, Tebas, dan Pemangkat. Selain itu, kontak sosial juga hampir sama dengan distribusi dan pergerakan yang berorientasi ke bagian selatan Sambas dan Tebas. Untuk dukungan infrastruktur, sebagai ibukota kabupaten, kondisi infrastruktur di Sambas terlihat lebih baik. Hal ini dapat dilihat dari fakta bahwa rata-rata dukungan infrastruktur untuk kegiatan sosial di Kabupaten Sambas telah mencapai di atas 50\%. Untuk kontak dengan daerah perbatasan, penduduk Sambas (rata-rata) hanya melakukan perjalanan ke daerah perbatasan atau utara (Paloh) setahun sekali, sedangkan untuk sebaliknya (bagian selatan), mereka melakukannya lebih sering, yaitu sebulan sekali. Mereka melakukan perjalanan ke Paloh sebagian besar untuk tujuan rekreasi, sedangkan menuju ke kota (bagian selatan) sebagai kunjungan keluarga.

Di Temajuk-Paloh, distribusi keluarga/teman sebagian besar berorientasi ke wilayah terdekat seperti Jawai, bagian selatan Kalimantan Barat/Sambas, Teluk Keramat, dan lainlain. Untuk pergerakan aktivitas sosial, negara tetangga (Sarawak) menjadi salah satu tujuan utama, disusul wilayah terdekat lainnya seperti Jawai, Teluk Keramat, Sambas, dan lain-lain. Untuk kontak sosial, sebagian besar penduduk di daerah perbatasan memiliki orientasi ke bagian selatan Sambas, bagian timur, Teluk Keramat, dan lain-lain. Infrastruktur di daerah perbatasan tidak banyak membantu. Telekomunikasi dan listrik adalah dua infrastruktur yang kurang didukung di daerah perbatasan. Untuk kontak dengan negara tetangga, penduduk Temajuk-Paloh melakukan perjalanan lebih sering ke Sarawak. Hampir sebulan sekali penduduk melakukan perjalanan ke Sarawak sebagian besar sebagai kegiatan rekreasi, sedangkan ke kota (bagian selatan) sebagai kunjungan keluarga.

\section{Interaksi Sosial}

Dari penjelasan sebelumnya, berdasarkan beberapa pengertian mengenai usaha, eksplorasi pada bagian ini akan dibatasi ke dalam beberapa informasi di antaranya adalah (1) orientasi transaksi utama, (2) arah kerja sama, (3) lokasi cabang usaha, (4) distribusi pegawai, (5) distribusi konsumen, dan (6) lokasi target penjualan. Dari semua indikator tersebut, analisis dilakukan dengan menyatukan seluruh variabel dalam satu tabel frekuensi atau perhitungan derajat. Adapun hasil pengukuran derajat yang dihasilkan ditampilkan pada Tabel 5, Tabel 6, dan Tabel 7.

Tabel 5. Interaksi (Jaringan) Usaha

\begin{tabular}{|c|c|c|c|c|c|c|c|c|c|}
\hline \multirow{2}{*}{ No } & \multirow{2}{*}{ Jaringan } & \multicolumn{4}{|c|}{ Sambas } & \multicolumn{4}{|c|}{ Temajuk, Paloh } \\
\hline & & Kode & Area & OutDegree & InDegree & Kode & Area & OutDegree & InDegree \\
\hline \multirow{3}{*}{1} & \multirow{3}{*}{$\begin{array}{l}\text { Usaha/ } \\
\text { Bisnis }\end{array}$} & 5 & Sambas & 42.000 & 15.000 & 2 & Paloh & 56.000 & 38.000 \\
\hline & & 7 & Sebawi & 31.000 & 24.000 & 5 & Sarawak & 27.000 & 33.000 \\
\hline & & 9 & Selatan & 7.000 & 11.000 & 4 & Sambas & 5.000 & 11.000 \\
\hline
\end{tabular}


Lanjutan Tabel 5

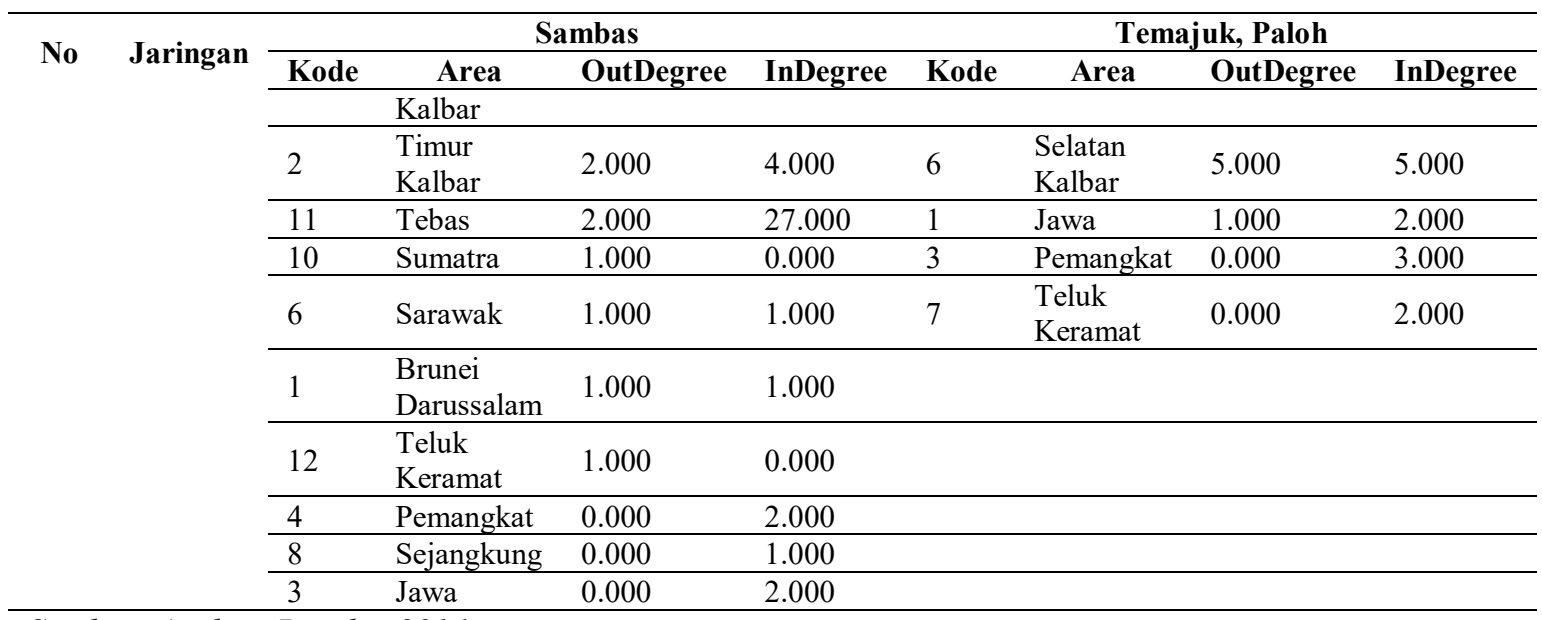

Sumber: Analisis Penulis, 2016

Tabel 6. Dukungan Infrastruktur dalam Jaringan Usaha di Sambas

\begin{tabular}{|c|c|c|c|c|c|}
\hline Variabel & Kategori & $\%$ & Variabel & Kategori & $\%$ \\
\hline \multirow{2}{*}{ Jalan } & Mendukung & 57.1 & \multirow{2}{*}{ Persampahan } & Mendukung & 50 \\
\hline & TidakMendukung & 42.9 & & TidakMendukung & 50 \\
\hline \multirow{2}{*}{ Listrik } & Mendukung & 57.1 & \multirow{2}{*}{ Telekomunikasi } & Mendukung & 88.1 \\
\hline & TidakMendukung & 42.9 & & TidakMendukung & 11.9 \\
\hline \multirow{2}{*}{ Air Bersih } & Mendukung & 78.6 & \multirow{2}{*}{ Koneksi Internet } & Mendukung & 73.8 \\
\hline & TidakMendukung & 21.4 & & TidakMendukung & 26.2 \\
\hline \multirow{4}{*}{$\begin{array}{l}\text { Fasilitas } \\
\text { Paling Buruk }\end{array}$} & Jalan & 31 & \multirow{4}{*}{$\begin{array}{l}\text { Fasilitas Paling } \\
\text { Baik }\end{array}$} & Jalan & 40.5 \\
\hline & Listrik & 26.2 & & Air Bersih & 40.5 \\
\hline & Air Bersih & 26.2 & & Telekomunikasi & 11.9 \\
\hline & Lainnya & - & & Lainnya & - \\
\hline \multirow{5}{*}{$\begin{array}{l}\text { Interaksi } \\
\text { dengan } \\
\text { Temajuk- } \\
\text { Paloh }\end{array}$} & Potensi & 40.5 & \multirow{5}{*}{$\begin{array}{l}\text { Interaksi dengan } \\
\text { Sarawak-Malaysia }\end{array}$} & Pasar Utama & 52.5 \\
\hline & Tidak Tahu & 35.7 & & Tidak Penting & 31 \\
\hline & Pasar & 11.9 & & Kebutuhan Harian & 7.2 \\
\hline & Tidak Penting & 7.1 & & Tidak Tahu & 4.8 \\
\hline & Lainnya & - & & Lainnya & - \\
\hline
\end{tabular}

Sumber: Hasil Survey, 2016

Tabel 7. Dukungan Infrastruktur dalam Jaringan Usaha di Temajuk-Paloh

\begin{tabular}{|c|c|c|c|c|c|}
\hline Variabel & Kategori & $\%$ & Variabel & Kategori & $\%$ \\
\hline \multirow{2}{*}{ Jalan } & Mendukung & 75 & \multirow{2}{*}{ Persampahan } & Mendukung & 71.9 \\
\hline & TidakMendukung & 25 & & TidakMendukung & 28.1 \\
\hline \multirow{2}{*}{ Listrik } & Mendukung & 18.2 & \multirow{2}{*}{ Telekomunikasi } & Mendukung & - \\
\hline & TidakMendukung & 81.8 & & TidakMendukung & 100 \\
\hline \multirow{2}{*}{ Air Bersih } & Mendukung & 87.5 & \multirow{2}{*}{ Koneksi Internet } & Mendukung & - \\
\hline & TidakMendukung & 12.5 & & TidakMendukung & 100 \\
\hline \multirow{4}{*}{$\begin{array}{l}\text { Fasilitas } \\
\text { Paling Buruk }\end{array}$} & Listrik & 65.6 & \multirow{4}{*}{$\begin{array}{l}\text { Fasilitas Paling } \\
\text { Baik }\end{array}$} & Jalan & 78.1 \\
\hline & Jalan & 18.7 & & Listrik (generator) & 9.4 \\
\hline & Telekomunikasi & 15,6 & & Air Bersih & 6.3 \\
\hline & Lainnya & - & & Lainnya & - \\
\hline \multirow{4}{*}{$\begin{array}{l}\text { Interaksi } \\
\text { dengan } \\
\text { Sarawak- } \\
\text { Malaysia }\end{array}$} & Pasar Utama & 53.1 & & & \\
\hline & $\begin{array}{l}\text { Kebutuhan } \\
\text { Harian }\end{array}$ & 31.2 & & & \\
\hline & Kerjasama & 3.1 & & & \\
\hline & $\begin{array}{l}\text { Penyediaan } \\
\text { Barang }\end{array}$ & 3.1 & & & \\
\hline
\end{tabular}




\begin{tabular}{cccccc}
\hline Variabel & Kategori & \% & Variabel & Kategori & $\%$ \\
\hline & Lainnya & - & & & \\
\hline Sumber: Hasil Survei, 2016 & & & & & \\
\hline
\end{tabular}

Aktivitas usaha atau bisnis di Sambas cenderung bergerak ke daerah terdekat dan internal sendiri, seperti Tebas dan Sebawi sampai kota-kota lain di bagian selatan Sambas (mengarah ke ibukota provinsi). Hal ini terjadi karena Tebas lebih dekat dengan Pontianak, dan kawasan ini dianggap sebagai salah satu pemasok utama untuk memenuhi aktivitas bisnis/usaha. Sebagian besar unit usaha di Sambas adalah usaha kecil dengan cabang dan jumlah karyawan yang terbatas. Sebagai ibukota kabupaten, sebagian besar infrastruktur telah mendukung kegiatan usaha di Sambas. Untuk interaksi dengan Temajuk-Paloh dan negara tetangganya (Sarawak-Malaysia), pelaku usaha dari Sambas menganggap Paloh sebagai daerah potensial, dan Sarawak sebagai daerah pasar utama.

Aktivitas usaha atau bisnis di Temajuk-Paloh mengarah ke Sarawak-Malaysia untuk transaksi dan pemasok utama mereka. Sebagian besar unit usaha di Temajuk-Paloh adalah usaha kecil tanpa cabang dan dikelola oleh pemiliknya sendiri. Sebagai salah satu wilayah paling ujung di Kalimantan Barat, infrastrukturnya sangat terbatas terutama untuk listrik dan telekomunikasi. Oleh karena itu, warga lebih sering berorientasi ke Sarawak. Sementara itu untuk interaksi dengan negara tetangga (Sarawak-Malaysia), pelaku usaha dari Temajuk-Paloh mengatakan bahwa Sarawak (terutama Melano) adalah pasar utama untuk aktivitas usaha mereka. Selain itu, Sarawak juga dianggap sebagai pemasok mereka untuk kebutuhan barang sehari-hari karena akses yang begitu dekat.

\section{Kesimpulan}

Dari beberapa temuan di atas, dapat disimpulkan bahwa interaksi (jaringan) sosial di Sambas cenderung mengarah ke bagian selatan Sambas mengarah ke ibukota provinsi (Kota Pontianak). Adapun pergerakan interaksi sosial di Temajuk-Paloh cenderung mengarah ke wilayah terdekat, seperti Jawai sampai Sarawak-Malaysia. Di Temajuk-Paloh, khususnya untuk kontak sosial dengan media, sebagian besar interaksi sosial lebih mengarah ke bagian selatan Sambas menuju ke ibukota provinsi. Hal ini disebabkan oleh penggunaan media telekomunikasi cenderung tidak menggunakan fasilitas fisik (misalnya, jalan, transportasi publik, dan lain-lain) yang tentunya dapat menjangkau tempat-tempat yang telah terhubung jaringan telekomunikasi.

Interaksi (jaringan) utama usaha di Sambas lebih berorientasi ke internal wilayah kabupaten sendiri seperti Tebas dan Sebawi. Namun, kedua lokasi ini merupakan wilayah yang mengarah ke selatan Sambas yang berorientasi ke ibukota provinsi (Kota Pontianak). Tentunya, dua wilayah tersebut mempunyai akses yang lebih dekat dari Sambas untuk mengarah ke Pontianak, sehingga bisa saja mempunyai keuntungan tertentu dalam pengembangan usaha. Adapun untuk interaksi (jaringan) usaha di Temajuk-Paloh juga cenderung bergerak ke sekitar wilayah sendiri dan negara tetangga (Sarawak). Hal ini bisa terjadi karena kurangnya infrastruktur pendukung untuk mencapai wilayah-wilayah lainnya di Kabupaten Sambas.

Melihat secara umum, analisis jaringan dapat dilakukan untuk melihat disparitas atau ketidakseimbangan interaksi "aliran" antardaerah. Dari hasil analisis, karena keterbatasan jarak dan infrastruktur, interaksi antara Sambas (sebagai kota), dan Temajuk, Paloh (sebagai daerah perbatasan) cenderung mempunyai karakteristik masing-masing dalam berinteraksi. Selain itu, pertimbangan kedekatan area dengan area tertentu juga berpengaruh. Terkait dengan infrastruktur pendukung interaksi sosial dan usaha, Sambas sebagai ibukota kabupaten dalam mengelola administrasi kewilayahan tentunya memiliki keunggulan dalam pendukung kegiatan sosial dibanding Temajuk-Paloh. Dalam hierarki 
perkotaan serta sebagai pusat pelayanan, Sambas tentunya diuntungkan dengan posisi dan hierarki. Menurut Simmie (2002), pusat atau ibukota biasanya terletak di pusat wilayah yang mampu melayani daerah sekitar serta memiliki frekuensi tinggi dalam jaringan usaha. Oleh sebab itu, tidak aneh jika pusat-pusat pelayanan menjadi orientasi utama dalam interaksi antardaerah. Selain itu, kawasan perbatasan mempunyai frekuensi interaksi yang cukup tinggi dengan wilayah negara tetangga. Hal ini dapat diperkuat sesuai dengan konsepsi kawasan perbatasan sebagai "ruang fungsional" yang dapat dimanfaatkan dari masing-masing negara (Wasti-Walter, 2009).

Interaksi kedua wilayah sepertinya belum mempunyai interaksi yang optimal. Sambas masih cenderung berorientasi ke bagian selatan mengarah ke ibukota provinsi, sedangkan Temajuk-Paloh masih cenderung berorientasi ke Melano-Sarawak (bagian utara). Hal ini dapat diterima karena kedekatan jarak antarwilayah/negara, serta keterbatasan dukungan infrastruktur yang menghubungkan kedua wilayah. Konektivitas dapat ditekankan dalam mengarahkan interaksi yang baik antara wilayah kota dan perbatasan. Dari perspektif jaringan perkotaan, implementasi kebijakan dapat diarahkan melalui peningkatan hubungan langsung antartitik (wilayah), mempersingkat pemisahan yang ada, mengurangi tahapan hubungan antarwilayah, atau penyediaan jalan pintas.

\section{Daftar Pustaka}

Albrechts, L., \& Seymour, M. (2005). The network society: A new context for planning. (L. Albrechts \& M. Seymour, Eds.) (First Edit). New York and London: Routledge.

Badan Pusat Statistik (BPS) Kabupaten Sambas. (2017). Kabupaten Sambas dalam angka tahun 2017. Sambas: Badan Pusat Statistik Kabupaten Sambas.

Bassi, I., Zaccarin, S., \& De Stefano, D. (2014). Rural inter-firm networks as basis for multifunctional local system development: Evidence from an Italian alpine area. Land Use Policy, 38, 70-79. doi:10.1016/j.landusepol.2013.10.021.

Borgatti, S. P., Everett, M. G., \& Freeman, L. C. (2002). UCINET for Windows: Software for social network analysis. Harvard, MA.

Borgatti, S. P., Everett, M. G., \& Johnson, J. C. (2013). Analyzing social networks (First Edition). California: SAGE Publications Ltd.

Clarke, N. (2009). Networks, urban. In R. Kitchin \& N. Thrift (Eds.), International Encyclopedia of Human Geography. Amsterdam: Elsevier.

Dale, C. (2003). The competitive networks of tourism e-mediaries: New strategies, new advantages. Journal of Vacation Marketing, 9(2), 109-118. doi:10.1177/135676670300900201.

Downs, J. A., \& Horner, M. W. (2012). Probabilistic potential path trees for visualizing and analyzing vehicle tracking data. Journal of Transport Geography, 23, 72-80. doi:10.1016/j.jtrangeo.2012.03.017.

Edmonds, E. A. (2007). Reflections on the nature of interaction. CoDesign International Journal of CoCreation in Design and the Arts, 3(3), 139-143. doi:10.1080/15710880701251427.

Glasson, J., \& Marshall, T. (2007). Regional planning. Abingdon-on-Thames: Routledge.

Hadas, Y. (2013). Assessing public transport systems connectivity based on Google Transit data. Journal of Transport Geography, 33, 105-116. doi:10.1016/j.jtrangeo.2013.09.015.

Hedaa, L., \& Törnroos, J.-Å. (2008). Understanding event-based business networks. Time \& Society, 172-3), 319-348. doi:10.1177/0961463X08093427.

Heydebrand, W. (1999). The network metaphor as key to the analysis of complex production and service relations in a global economy. New York. Retrieved from https://d-nb.info/1024490335/34.

Knoke, D., \& Yang, S. (2008). Social network analysis. Thousand Oaks: SAGE Publications Ltd.

Krejcie, R. V., \& Morgan, D. W. (1970). Determining sample size for research activities. Educational and Psychological Measurement, 30(3), 607-610. doi:10.1177/001316447003000308.

Lobo-Guerrero, L. (2012). Connectivity as the strategization of space - the case of the Port of Hamburg. 
Distinktion: Scandinavian Journal of Social Theory, 13(3), 310-321. doi:10.1080/1600910X.2012.697860.

Miller, N. J., Besser, T., \& Malshe, A. (2007). Strategic networking among small businesses in small US communities. International Small Business Journal: Researching Entrepreneurship, 25(6), 631-665. doi:10.1177/0266242607082525.

Muazir, S., \& Hsieh, H.-C. (2013). Borderlands and tourism development in Kalimantan Island: Kalimantan Barat, Indonesia - Sarawak, Malaysia "Head to Head." Journal of Design And Built Environment, 13, 112. Retrieved from https://ejournal.um.edu.my/index.php/jdbe/article/view/5336/3125.

Muazir, S., \& Hsieh, H.-C. (2016). Social activity and adaptive urban network in strategic areas in Indonesia. Theoretical and Empirical Researches in Urban Management, 11(3), 62-77. Retrieved from https://econpapers.repec.org/article/romterumm/v_3a11_3ay_3a2016_3ai_3a3_3ap_3a62-77.htm.

Muazir, S., Hsieh, H.-C., \& Lestari, L. (2014). Infrastructure network in a strategic region: Transportation connectivity and accessibility in Sambas Regency, West Kalimantan. In Border and Development International Conference, Pontianak, Indonesia. Pontianak: Universitas Tanjungpura.

Murdock, C. (2010). Changing places: Society, culture, and territory in the Saxon-Bohemian Borderlands, 18701946. Michigan: University of Michigan Press.

Nazara, S., Hewings, G. J. D., \& Sonis, M. (2006). An exploratory analysis of hierarchical spatial interaction: The case of regional income shares in Indonesia. Journal of Geographical Systems, 8(3), 253-268. doi:10.1007/s10109-005-0016-3.

Neuman, M. (2006). Infiltrating infrastructures: On the nature of networked infrastructure. Journal of Urban Technology, 13(1), 3-31. doi:10.1080/10630730600752728.

Oliveira, M., \& Gama, J. (2012). An overview of social network analysis. Wiley Interdisciplinary Reviews: Data Mining and Knowledge Discovery, 2(2), 99-105. doi:10.1002/widm.1048.

Pache, G. (1990). The role of small business in the development of network organisation: The case of France. International Small Business Journal: Researching Entrepreneurship, 8(4), 71-76. doi: $10.1177 / 026624269000800405$.

Scott, N., Baggio, R., \& Cooper, C. (2008). Network analysis and tourism from theory to practice. (C. Cooper, C. M. Hall, \& D. Timothy, Eds.). Clevedon/Buffalo/Toronto: Channel View Publications.

Simmie, J. (2002). Trading places: Competitive cities in the global economy. European Planning Studies, 10(2), 201-214. doi:10.1080/09654310120114490.

Sokol, M. (2009). Regional connectivity. In R. Kitchin \& N. Thrift (Eds.), International Encyclopedia of Human Geography (Vol. 9, pp. 165-180). Oxford: Elsevier.

Staeheli, U. (2012). Listing the global: Dis/connectivity beyond representation? Journal of Social Theory, 13(3), 233-246. doi:10.1080/1600910X.2012.724646.

Takahashi, K., \& Sakamoto, A. (2000). Assessing social relationships in adolescents and adults: Constructing and validating the affective relationships scale. International Journal of Behavioral Development, 24(4), 451-463. doi:10.1080/016502500750038008.

Tinsley, R., \& Lynch, P. (2001). Small tourism business networks and destination development. International Journal of Hospitality Management, 2044), 367-378. doi:10.1016/S0278-4319(01)00024-X.

Todeva, E. (2006). Business networks, strategy and structure. Routledge.

Vega, A. (2012). Accessibility and the local concentration of economic activity: A case study for county Galway. Irish Geography, 45(1), 25-44. doi:10.1080/00750778.2012.729917.

Wasti-Walter, D. (2009). Borderlands. Elsevier Ltd. 